\title{
Intra-Market Linkages in the Financial Sector and Their Effects on Financial Inclusion
}

\author{
Caspah Lidiema \\ Department of Economics, Accounts, \& Finance, Jomo Kenyatta University of Agriculture and Technology, Nairobi, Kenya
}

Email address:

lidiema.research@gmail.com

To cite this article:

Caspah Lidiema. Intra-Market Linkages in the Financial Sector and Their Effects on Financial Inclusion. International Journal of Finance and Banking Research. Vol. 4, No. 5, 2018, pp. 79-90. doi: 10.11648/j.ijfbr.20180405.11

Received: October 5, 2018; Accepted: October 17, 2018; Published: November 7, 2018

\begin{abstract}
The financial stability objective of any financial system authority is to maintain confidence, and promote the safety and soundness of the domestic financial system. Financial stability has been defined as the resilience of the financial system in the face of adverse shocks to enable the continued smooth functioning of the financial intermediation process. The Kenyan Financial service providers are diverse and they include 42 commercial banks, 49 insurance companies, 12 deposits taking microfinance banks, and 199 registered savings and credit cooperatives (SACCOs). This paper examined financial intramarket linkages (dynamic relationship and volatility spillovers) effects between the Commercial banks and other financial sector segments (Insurance and Capital Markets) in Kenya and the impact of this transmission on financial inclusion. The study evaluated the effect of intra-market linkages on financial inclusion using Bayesian Vector Autoregressive (BVAR) using monthly data from the Kenyan market during the period January 2004 - December 2016. Impulse-response analysis and forecast error variance decomposition were used to investigate these intra-market linkages and their causal effect to financial inclusion. Results show that there are significant market interactions and interlinkages with significant shocks transmission moving from banks to other markets. Interest rates shock transmission affected all markets. This means that monetary policy transmission as expected trickles down to the entire financial sector. The study also found out that, positive shocks from credit impacts positively on lending rate and the capital markets performance implying banking mechanism to reward increased loan uptake at cheaper prices and hence creating cash-flow that spills over to more investment on the Nairobi Securities Exchange. The study recommends that policy makers design policies that help minimize the adverse impact of volatility/shocks but create opportunities for growth on each market to foster price stability and increase investments through financial inclusion.
\end{abstract}

Keywords: Spillover, Commercial Banks, BVAR, Shocks, Volatility, Financial Sector

\section{Introduction and Motivation}

\subsection{Background on the Study}

The financial stability objective of any financial system authority is to maintain confidence, and promote the safety and soundness of the domestic financial system. Financial stability has been defined as the resilience of the financial system in the face of adverse shocks to enable the continued smooth functioning of the financial intermediation process. Effective financial intermediation, which involves the ability of many households and businesses to channel savings into productive investments with confidence, is essential for sustained economic growth. This, therefore, means that Financial Inclusion is key to the economy and hence the depth of Financial Inclusion could determine the soundness of any financial system. Sahay et al. [1] define Financial Inclusion as the access to and use of formal financial services. The idea is that finance should be available to as many as possible for a variety of uses: accounts to receive income or transfers, savings accounts to store money safely and prudently, credit sources for personal or business borrowings, and insurance products to tide against bad times.

Chakraborty [2] asserts that Financial Inclusion is the process of ensuring access to appropriate financial products and services needed by all sections of society including vulnerable groups such as weaker sections and low income groups at an affordable cost in a fair and transparent manner by mainstream institutional players. Sahay et al. [1] further stated that, financial sectors have evolved across the globe 
and modern financial systems have become multifaceted. Regarding financial institutions, banks are typically the largest and most important, investment banks, insurance companies, mutual funds, pension funds, venture capital firms, and many other types of nonbank financial institutions now play substantive roles. The researchers further state that, financial markets have evolved in ways that allow individuals and firms to diversify their savings and firms to raise money through stocks, bonds, and foreign exchange markets. It is this growth of financial institutions and markets that help in facilitating the provision of financial services. The most important thing will depend on the efficiency of and access to these financial services to help shape the level and rate of increasing economic prosperity. The Kenyan Financial service providers are diverse and they include 42 commercial banks, 49 insurance companies, 12 deposits taking microfinance banks, and 199 registered savings and credit cooperatives (SACCOs). However, the Kenyan Financial system is dominated by the commercial banks. This means that safeguarding financial system stability is key in stabilizing the general economy. It is a legal mandate of the Central Bank of Kenya (CBK) to manage monetary policy and enhance financial stability in Kenya. Generally, the financial system in Kenya includes commercial banks, nonbank financial institutions, mortgage companies, forex bureaus, pension schemes, SACCOs, the insurance sector and the stock market.

This means that, financial system is much wider than commercial banks and therefore there is great need to maintain stability in the sector otherwise, any monetary policy or shocks to any of segments can easily spill over to the other segments within the financial system which could eventually lead to a financial a systemic crisis. Cheng and Degryse [3] assert that bank deposit equals the ratio of the savings in the banking system to local GDP. Bank Deposit is a measure of the financial depth of the local banking sector. He further argues that bank credit, which equals the credit extended by banks to local enterprises over local GDP, is a second most important indicator. This indicator measures the financial resources provided by banks to other entities.

\subsection{Problem Statement}

Commercial banks in Kenya are the main driving force of the financial sector accounting for the largest share of the assets of all financial institutions. This is mainly due to the absolute size of the commercial banks, and their relative importance as the principal institutions in the flow of funds between savers and borrowers. Banking Industry dominance is hugely contributed to by the dominance of commercial banks. In its entirety, Commercial banks are usually the most affected directly with the level of financial system regulation especially the monetary policy regulation. Elementary and common knowledge about commercial banks is that they mainly receive deposits from customers and then invest those deposits by making loans to their customers. Although these are the two main functions that represent a large proportion of their activities, commercial banks participate in a much wider spectrum of financial services than two activities imply. Commercial banks also support other segments in the financial system through their Balance-sheet transactions and off-balance-sheet transactions. Balance-sheet transactions are usually presented in the normal Yearly Financial statements while the Off-balance-sheet items are contingent liabilities transactions which are never presented in the Financial Statements. Due to the interlink between Commercial banks and other financial sector segments, any market shocks due to policy or otherwise will not only affect the banks but also the other segments like the Capital markets, Pension funds, insurance and even the savings and Credit cooperatives (SACCOs). For example, a client that is unable to repay a loan will also be likely unable to pay their monthly insurance premium or pension contribution in a defined contribution scheme. The evidence gathered implies that that financial sector is key to economic growth and particularly in capital accumulation through savings and credit. It also appears that monetary policy plays a big role in influencing economic growth through its policies which mostly affects banks. A few studies have been conducted to investigate the effect of monetary policy transmission and economic growth. (see Cevik and Teksoz [4], Gali and Gambetti [5]). However, none of these studies have analyzed the impact of these policies in relation to deepening financial Inclusion. In view of these shortcomings, the current study will contribute to the literature of knowledge with the new analysis using quarterly data.

\subsection{Study Objectives}

\subsubsection{General Objective}

To analyze the intra-market linkages in the Financial sector the effect on Financial Inclusion.

\subsubsection{Specific Objectives}

(1) To investigate the intra-market financial sector linkages (Market Players and Financial System)

(2) To determine the effect of Financial sector intra-market linkages on Financial Inclusion

\subsection{Hypothesis}

The Following three null hypotheses will be tested under this study:

(1) $\mathrm{H}_{0}$ : There is no Financial Sector Intra-market linkages

(2) $\mathrm{H}_{0}$ : Financial Sector Intra-market linkages do not affect Financial Inclusion

\subsection{Value of the Study}

The findings of this study will be a significant contribution to the existing literature on Financial Inclusion and financial intra-market spillovers. Since this is an area that has great potential for further growth and will attract further academic research, the findings will assist in providing reference materials for future researchers. Policy makers in the Kenyan Financial Sector will also get a footing on how monetary policy affecting financial inclusion also spill over within the 
financial sector segments and how to address any shortfalls and enhance growth without affecting financial inclusion.

The findings can also assist the Kenyan Government to know the effects on monetary policies that affect the entire Financial Sector and hence put in place suitable regulations to enhance the sustainable economic growth and financial inclusion.

The rest of the study is structured as follows: Section 2 highlights the comprehensive overview of the empirical literature; Section 3 presents the methodology and data issues; Section 4 will report the results of the empirical analysis and Section 5 will conclude the study and provides policy implications and recommendation to the industry players and the Government of Kenya.

\section{Literature Review}

\subsection{Empirical Review}

Credit represents the loans banks make to individuals and their businesses. Tight monetary policies can reduce the amount of credit, because banks do not generate enough income from the interest rates on loans. The interest rate on loans is directly affected by the prime rate set by the central bank of any financial system. Individuals and businesses with insufficient capital balances may also be unable to repay personal or business loans. Banks are usually unwilling to loan money when individuals or businesses cannot repay the balance. Sahay et al. [1], studied the measurement of financial development index. They used data between 1980 and 2013 for 176 advanced, emerging, and low-income economies from the World Bank Global Financial Development Database. The authors employed a dynamic system Generalized Method of Moments (GMM) estimator and their results showed that banking system credit to the private sector, while still a relevant component of financial development, has a weight of 0.25 within the depth subcomponent of Financial Institutions. They concluded that bank credit still plays an important role, reflecting the role of banks in many financial systems, but it is far from being the only driver of the results.

Cummins et al. [6] analyzed the market value impact of operational risk events on non-announcing firms in the U. S. banking and insurance industries. The main aim of the study was to seek evidence of positive or negative intra or intersector spillover effects on stock prices in the commercial banking, investment banking, and insurance industries. The authors employed the GARCH Model utilizing operational loss events from the Algo OpData database compiled by Algorithmic from 1978 through 2010. Results proved that that operational risk events cause significant negative intra and inter-sector spillover effects. However, these results showed that the spillovers are information-based rather than purely contagious.

Kim. H. S [7] examined the Spillover Effects of Pension Funds on Capital Markets of 21 OECD countries. Time series data for 21 OECD member countries based on the ratio of autonomous pension funds to GDP from the OECD (2003, 2005) was used. Other data from World Development Indicators (2005) was also included covering a span of 1991 to 2003 was also included. The Generalized Method of Moments for the dynamic panel model developed by Arellano and Bond (1991) was employed. Results showed that the development of pension funds has a unilateral Granger-causality for long-term investments in the development of capital markets. These results were also compared with the estimation results of a similar model for life insurance, those for pension funds seem unique and they found out that the accumulation of pension funds works as a beneficial shock to capital markets while life insurance evolves endogenously together with capital markets.

Cheng and Degryse [3] analyzed the Impact of Bank and Nonbank Financial Institutions on Local Economic Growth in China. The study employed data from 27 Chinese provinces over the period 1995-2003 using the Generalized Method of Moments (GMM). The main objective was to establish if the financial development of two different types of institutions (banks and nonbank financial institutions) has a significantly different impact on local economic growth. The result indicated that only banking development showed a statistically significant and economically relevant impact on local economic growth.

Chodorow-Reich [8] investigated the effects of unconventional monetary policy on financial institutions. Using high-frequency event studies, the author found the introduction of unconventional policy in the winter of 200809 in the US had a strong, stabilizing impact on banks and especially on life insurance companies, consistent with the positive effects on legacy asset prices and future business dominating any impulse for additional risk taking. The striking feature of the results is that the interaction of low nominal interest rates and administrative costs led money market funds to waive fees, producing an incentive to reach for higher returns to reduce waivers. The author results showed that private defined-benefit pension funds with worse funding status or shorter liability duration also seemed to have reached for higher returns beginning in 2009, but again such behavior mostly dissipated by 2012. In his summary, the author stated that unconventional monetary policy helped to stabilize some sectors and provoked modest additional risk taking in others.

King and Levine [9] conducted a research on the Finance and Growth nexus using data averaged over the 1960-1989 period and a pooled cross-country, time-series study using data averaged over the 1960s, 1970s, and 1980s. They performed simple regression and correlation analysis and their results showed that financial development determines long-run economic growth, capital accumulation and productivity growth. This therefore implies that finance through Savings and Credit could spur economic growth and increasing the depth of financial inclusion index.

King and Levine [10] argued that in focusing attention on the nexus of finance, entrepreneurship, and innovation, then the financial system can be the lubricant for the main engine 
of growth. Better financial services expand the scope and improve the efficiency of innovative activity; they thereby accelerate economic growth. They further argue that financial repression correspondingly reduces the services provided by the financial system to savers, entrepreneurs, and producers; it thereby impedes innovative activity and slows economic growth. From this study, the results showed that market and policy development can impact savers and borrowers and hence affect financial inclusion through some or all segments of the financial sector and hence impact on economic growth.

Levine and Zervos [11] analyzed the effect of stock markets and banks promote economic Growth. Using a sample of 42 countries over the period 1976-1993 and applying regression analysis, the results showed that even after controlling for many factors associated with growth, stock market liquidity and banking development are both positively and robustly correlated with contemporaneous and future rates of economic growth.

Wei [12] analyzed the interest rate mean and volatility spillover to the industrial production index and two China stock markets by employing the Constant Conditional Correlation (CCC) and Dynamic Conditional Correlation (DCC) MGARCH $(1,1)$ model. The author found that China contractionary monetary policy has a positive impact on the China economic growth and stock markets.

\subsection{Research Gap}

Several studies in the world have developed a sizeable literature on financial inclusion but very few have tackled the issue of the depth of financial inclusion. Equally few studies that have studied spillovers within the financial sectors have dealt mostly on the operational risk. While studies on spillover effect have concentrated on inter-sector effects of operational loss events on commercial banks, investment banks and insurers these studies mostly geared toward confirming the intra and inter-sector effects on the degree of integration of the financial services industry. Most the mentioned research studies have employed General Method of Moment model, but none of them addresses the effect of monetary policy implications on the intra-market spillovers in the financial sector and the general depth of financial inclusion comprehensively. The researcher also noted that the new market development of interest capping under new banking Act 2016 could bring new dynamics to the depth of financial inclusion with structural changes in the savingscredit model by financial institutions and hence have an effect to the economy. The study will test the outline hypotheses by answering the following three Research questions; 1. Does the Financial Market segments have any inter-linkages; 2. To what extent does the intra-market linkages affect each segment (short run and Long run effects); 3 . What is the effect of the intra Market linkages in 1 (if any) have on Financial Inclusion; So far, there has been little empirical evidence on the effect of monetary policy on Financial Inclusion and financial intra-segment linkages. The study aims to bridge this gap.

\section{Data and Methodology}

\subsection{Introduction}

The monthly household credit, monthly Insurance net premiums paid, monthly Nairobi Stock Exchange (NSE) 20share Index and monthly Lending rate (as a representation of policy direction in the market) was used in this study. The data spanning the period January 2004 to December 2016 was collected from various sources including Central Bank of Kenya website, Nairobi Securities Exchange and Kenya Bankers Association (KBA). Data was analyzed using Bayesian Vector Autoregressive (BVAR) Model. Serwa and Wdowinski [13], argues that the most fashionable tool to research the linkages between business and monetary cycles within the short and medium run could be a vector autoregressive (VAR) model. This study employed the impulse-response analysis and forecast error variance decomposition to investigations these intra-market linkages and their causal effect to financial inclusion.

\subsection{Estimation with Bayesian VAR}

Vector Autoregressive (VAR) Models were propped by Sims [14] in the paper titled "Macroeconomics and reality". The author argued that VARs should replace large-scale macro-econometric models inherited from the 1960s because the latter imposed incredible restrictions, which were largely inconsistent with the notion that economic agents take the effect of today's choices on tomorrow's utility into account. VARs have since been used to model and forecast may macroeconomic factors and often used for econometric analysis and in the evaluation of proofs of economic theories. Some of this studies include; Chen and Liao [15], De Medeiros et al. [16] and Pecican [17]. Bayesian vector autoregression (BVAR) builds on VAR model by employing Bayesian methods to estimate a vector auto regression (VAR). In that respect, the difference with standard VAR models lies in the fact that the model parameters are treated as random variables, and prior probabilities are assigned to them. While Sims [18] states that the objective aspect of Bayesian inference is the set of rules for transforming an initial distribution into an updated distribution conditional on observations. Villani [19] argues that Bayesian priors are often used to restrain the otherwise highly over-parametrized vector autoregressive (VAR) models.

The role of the Bayesian prior is to prohibit coefficients to be non-zero. The main advantage of Bayesian vector autoregressive (BVAR) model is that it avoids the problems of collinearity and over-parameterization that often occur with the use of VAR models since BVAR imposes priors on the AR parameters. A multivariate time series $r_{t}$ is a VAR process of order 1, or VAR (1), if it follows the model.

$$
\mathrm{r}_{\mathrm{t}}=\alpha_{0}+\beta_{\mathrm{i}} \mathrm{r}_{(\mathrm{t}-\mathrm{i})}+\varepsilon_{\mathrm{i}} \#
$$

where $r_{t}$ for $t=1, \cdots, T$ is an $K \times 1$ vector of observations for is a $\mathrm{K}$-dimensional vector, $\beta_{\mathrm{i}}$ is a $\mathrm{K} \times \mathrm{K}$ matrix and $\varepsilon$ is a white noise with zero and positive definite covariance matrix. 
$\sigma$ or $\varepsilon \sim \operatorname{iidN}(0, \sigma)$. Tsay [20] asserts $\varepsilon$ is often assumed to be multivariate normal. the above can be a generalized $\operatorname{VAR}(\mathrm{p})$ as

$$
\mathrm{r}_{\mathrm{t}}=\alpha_{0}+\sum(\mathrm{i}=1)^{\mathrm{p}} \beta_{\mathrm{i}} \mathrm{r}_{(\mathrm{t}-\mathrm{i})}+\varepsilon_{\mathrm{i}} \#
$$

Define $\mathrm{Y}$ as $\mathrm{T} \times \mathrm{K}$ matrix for $\mathrm{T}$ observations. Let $\varepsilon$ and $\mathrm{E}$ represent errors for $r_{t}$ and $Y$ respectively. For $t=1, \cdots, T$, the above equation can be written in compact form as

$$
\mathrm{Y}=\mathrm{BZ}+\mathrm{E} \#
$$

Where, $\quad Y=\left[r_{\mathrm{i}}, \cdots, \mathrm{r}_{\mathrm{T}}\right], \mathrm{B}=\left[\mathrm{v}, \beta_{1}, \cdots, \beta_{\mathrm{p}}\right], \mathrm{E}=$ $\left.\varepsilon_{1}, \cdots, \varepsilon_{-} \mathrm{T}\right], \mathrm{Z}=\left[\mathrm{Z}_{-} 0, \cdots, \mathrm{Z}_{-}(\mathrm{T}-1)\right]$

$$
\mathrm{Z}_{\mathrm{t}}=\left[\begin{array}{c}
1 \\
\mathrm{y}_{\mathrm{t}} \\
\vdots \\
\mathrm{y}_{\mathrm{t}-\mathrm{p}+1}
\end{array}\right] \#
$$

Where, $t=1, \cdots, \mathrm{T}$ is a $1 \times \mathrm{p}$ matrix of observations, $\mathrm{B}_{\mathrm{i}}$ is a $p \times p$ matrix of coefficients for $i^{\text {th }}$ lap. $k$ is the maximum number of lags and $\varepsilon_{\mathrm{i}}$ are residuals. The model was identified using the Cholesky decomposition of the error covariance matrix.

Where, $Y=\left[r_{i}, \cdots, r_{T}\right], B=\left[v, \beta_{1}, \cdots, \beta_{p}\right], E=$ $\left.\varepsilon_{1}, \cdots, \varepsilon_{-} T\right], Z=\left[Z_{-} 0, \cdots, Z_{-}(T-1)\right]$

\subsection{BVAR using Sims-Zha Prior (SZBVAR)}

This study uses Sims and Zha [21] prior. The Sims-Zha
BVAR allows for a more general specification and can produce a tractable multivariate normal posterior distribution (Adenomon and Evans [22]). This BVAR model is based a specification of the dynamic simultaneous equation representation of the model. The prior is constructed for the structural parameters. The prior covariance matrix of the errors, S(i), is initially estimated using a VAR(p) model via OLS, with an intercept and no demeaning of the data.

Therefore, re-write an m-dimensional multivariate reduced VAR model as

$$
\mathrm{y}_{\mathrm{t}}=\mathrm{c}+\mathrm{B}_{1} \mathrm{y}_{\mathrm{t}-1}+\cdots+\mathrm{B}_{\mathrm{k}} \mathrm{y}_{\mathrm{t}-\mathrm{k}}+\varepsilon_{\mathrm{i}} \#
$$

where $t=1, \cdots, \mathrm{T}$ is a $1 \times \mathrm{p}$ matrix of observations, $B_{i}$ is a $\mathrm{p} \times \mathrm{p}$ matrix of coefficients for $i^{\text {th }}$ lap. $k$ is the maximum number of lags and $\varepsilon_{\mathrm{i}}$ are residuals. The model was identified using the Cholesky decomposition of the error covariance matrix.

\section{Results and Discussion}

First is the discussion of the data used. The paper used time series data for interest rates, Household Credit, NSE 20 share index and insurance premium from January 2004 to December 2016. The data plots exhibit continuous upwards trend with fluctuations. The movements of the plots in Figure 1 indicate that the mean and the variance of the markets data are changing over time. This means that the mean is nonconstant and the variance is unstable.

Market Trends

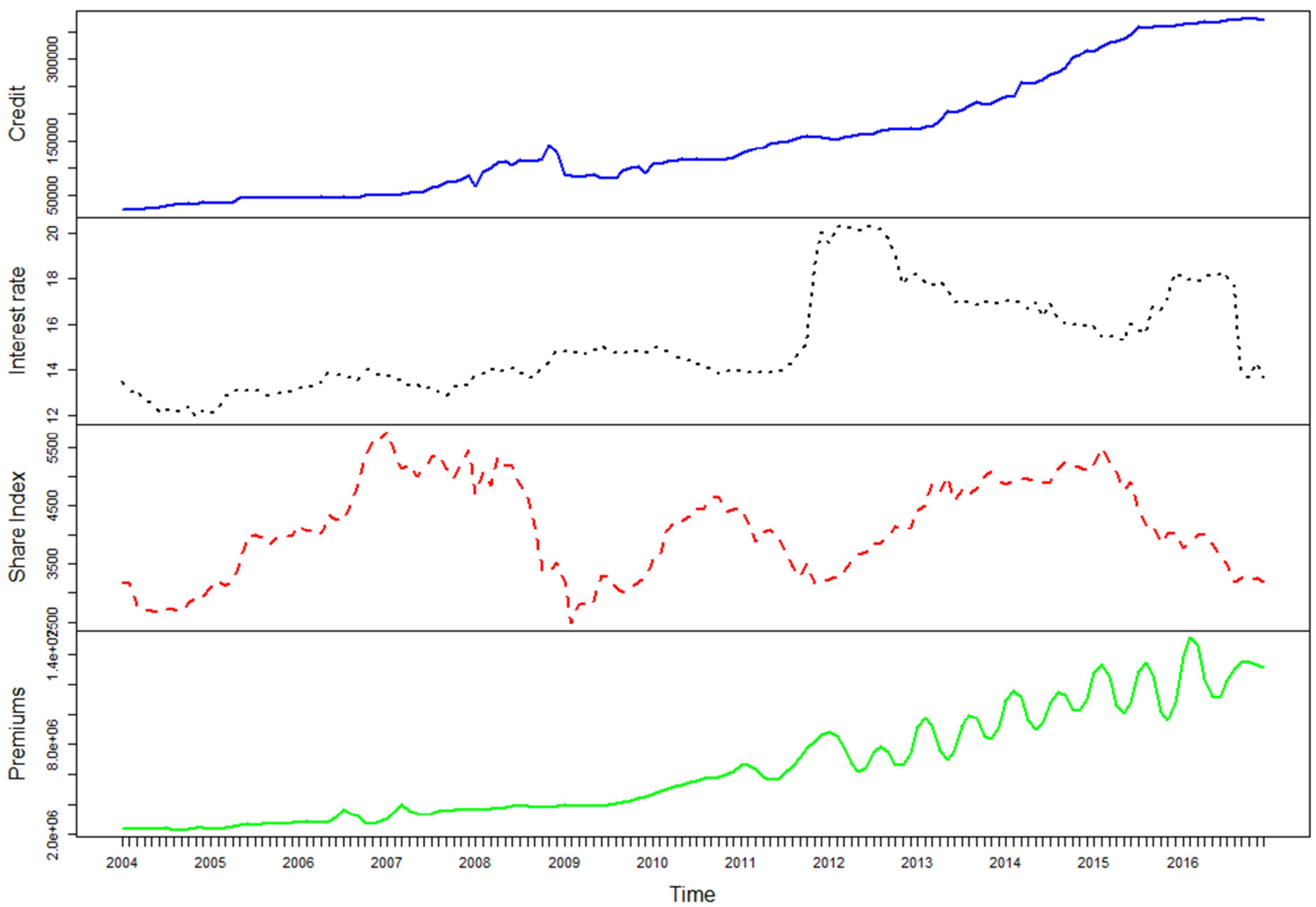

Figure 1. Market trends for Household Credit, Lending rate, Share Index and Insurance Premium. 


\subsection{Descriptive Statistics}

From a sample 156 observations, descriptive statistics as presented in Table 1 indicated that returns of the variables in the study are not normal except the Foreign exchange returns as indicated by the Jarque-Berra tests. Skewness of household Credit and NSE 20-share index is negative and positive for Lending rates, Insurance premium and Foreign exchange markets (the skewness of the normal distribution or any perfectly symmetric distribution is zero). The statistics also indicate the distribution is heavy-tailed as the Kurtosis is less than (The kurtosis of the normal distribution is 3 ).

Table 1. Descriptive statistics for log returns.

\begin{tabular}{llllll}
\hline & H. Credit & Lend rate & NSE_Index & Ins-Pre & Forex \\
\hline Mean & 11.67 & 8.3 & 8.3 & 15.51 & 4.4 \\
Max & 12.83 & 3.01 & 8.66 & 16.53 & 4.66 \\
Min & 10.14 & 2.48 & 7.81 & 14.64 & 4.14 \\
Std. Dev & 0.78 & 0.14 & 0.21 & 0.57 & 0.13 \\
Skewness & -0.14 & 0.58 & -0.34 & 0.1 & 0.13 \\
Kurtosis & -1.08 & -0.66 & -0.95 & -1.35 & -0.57 \\
J-B Statistics & $7.79(0.021)$ & $11.42(0.016)$ & $8.56(0.021)$ & $11.7(0.007)$ & $2.34(0.226)$ \\
\hline
\end{tabular}

Significant Level for Jarque-Berra Statistic is 5\% Level

\subsection{Impulse Responses to Shocks from (Interest Rate) Policy Variables}

From the impulse responses in Figure 2, negative shocks from interest rates have a negative effect in the household credit uptake albeit in the short run especially within 6 months after which the credit uptake reverts to normal bounds. A one standard deviation shock to Lending rates causes significant decreases in credit uptake for between 3-5 months after which the effect dissipates. However, it is important to note that this

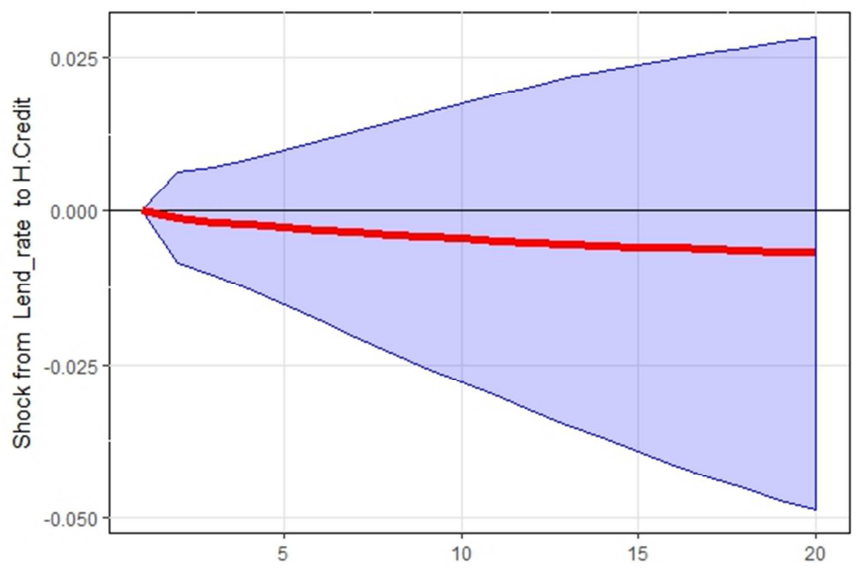

change is not significant. On the other hand, a one standard deviation shock to credit uptake causes significant depreciation of the local currency but there is no shock transmission from Forex to Credit uptake. This implies that Price of credit does not matter to borrowers but the availability of loans is key. The inverse impact of credit to lending rates could signal that if banks increase more customers in their loan book could lead to favorable prices to customers as banks would leverage cheaper loans for higher returns.

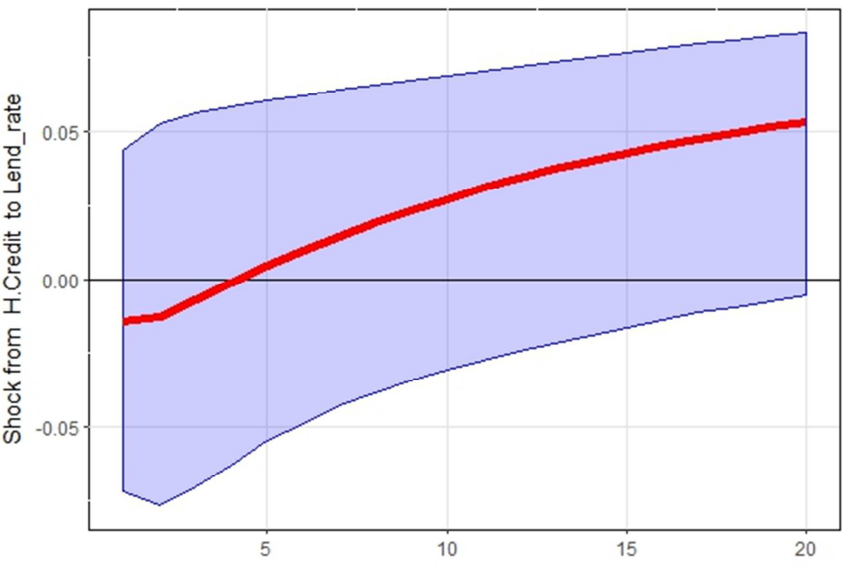

Figure 2. Response Impulses Credit and Interest without Forex.

Figure 3, clearly indicates that introduction of the Foreign Exchange rate innovations into the equation does not change the shock transmission behavior. This could be attributed to the fact that Exchange rate does not affect loan uptake as much as monetary policy changes. This is confirmed by the variance decomposition in Table 2 where spillover effect from exchange rates household credit is only $0.02 \%$. 

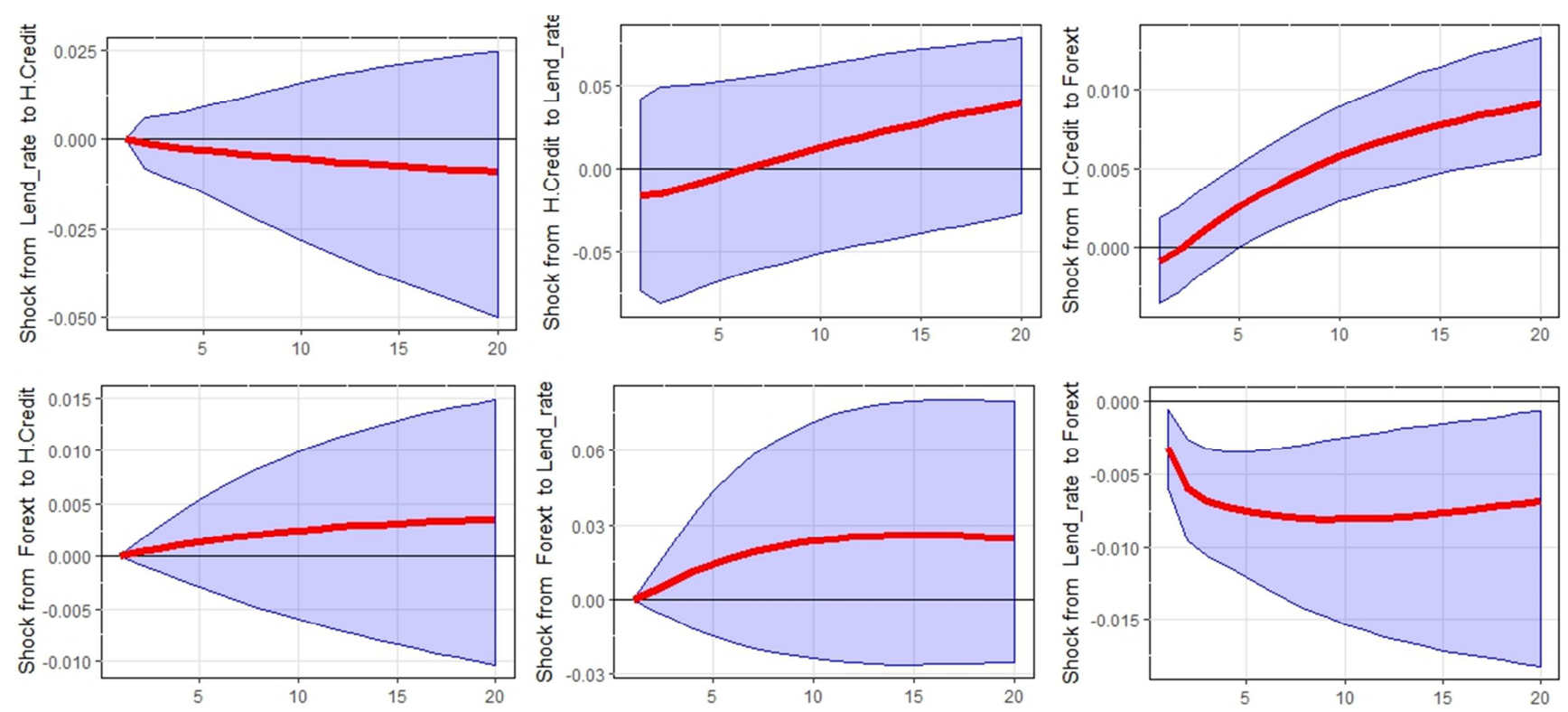

Figure 3. Response Impulses Credit and Interest with Forex.

Table 2. Decomposition of Forecast Errors for a Market interactions (Forex).

\begin{tabular}{lllll}
\hline & Monetary Policy & NSE Index & Insurance & Forex \\
\hline Monetary Policy & 99.95 & 0.01 & 0.02 & 0.03 \\
NSE Index & 19.79 & 79.37 & 0.38 & 0.46 \\
Insurance & 7.35 & 1.35 & 90.46 & 0.84 \\
Forex & 16.34 & 1.2 & 3.3 & 83.09 \\
Contribution Inc. own & 143.43 & 81.93 & 94.16 & 84.42 \\
Net Volatility & 43.43 & -18.07 & -5.84 & -15.58 \\
\hline
\end{tabular}

Source: Authors Calculations

\subsection{Market Interactions}

Theoretically, monetary policy transmission is expected to flow from the dominant player (Commercial Banks) to other markets. To test if there is transmission between markets in either sides can be tested using correlations from VAR model. A BVAR model that included the three markets i. e. Banking, Insurance, Capital and markets was developed. Results indicate that negative shocks in banking industry leads to a negative impact in the Capital markets within the first 6 periods after which the markets will stabilize before starting to pick up steadily. The same effects in the banking segment negatively and significantly affects Foreign exchange markets.

However, just like before, the exchange rate markets does not have an impact in either of the markets save for the insurance segment where unfavorable exchange rates positively impact the increase in premium collections. This could imply that favorable exchange rates could signal more supply in local currency and hence the markets channel the same to pay premiums. This could also imply more local currency supply from remittances. This is confirmed with similar results where unfavorable Foreign exchange also leads to unfavorable interest rate as the Central bank uses increased Central Bank rate (CBR) to reduce local currency money supply in the market. Figures 5 to 10 indicate the shock transmission between markets in the financial sector. Figure 5 shows that contractionary monetary policy leads to improved performance of the stock market hence agreeing with the study by Wei [12].

Without including Foreign exchange markets, variance decomposition (Table 3) based on a 10-step ahead forecasts show that Monetary policy (banking interest rates) is the largest contributor of volatility to other markets (Stock market and Insurance) contributing about $16.42 \%$. This volatility spillover is one way as the other markets do not contribute to the spillover but are rather net recipients. The insurance sector is the largest recipient of the financial market volatility spillover at $9.16 \%$. This implies that other than banks negative effects of monetary policy will affect the insurance sector. The stock market receives about $6.5 \%$ of the spillovers in the market.

Table 3 indicates the variance decomposition results when foreign exchange markets are included. The same trend, where the monetary policy (banking interest rates) is the net supplier of volatility at $43 \%$ to other markets. The most interesting fact is that; the stock market now is the net recipient of the financial volatilities at $18 \%$. This signifies the close relationship between the stock markets and the foreign exchange markets. This implies the significance of foreign 
currency flows into the stock market driven by foreign investors trading patterns that drive demand or flight of stocks from the Nairobi Securities Exchange. The Insurance sector is the least recipient at $6 \%$. This implies that most of the shocks from the banking sector are absorbed by foreign exchange markets and stock markets before the effect is felt by the insurance sector. This could be explained by the slow penetration of insurance sector in Kenya and to which the lower volatility effect to insurance sector. Another observation from this is the fact that since most banks are offering insurance products within the banc-assurance model, the negative effects to the insurance industry are also being absorbed by the banks but since banks are the net supplier of volatilities the leverage if already captured before the net effect.

Table 3. Decomposition of Forecast Errors for a Market interactions (No Forex).

\begin{tabular}{llll}
\hline & Monetary Policy & NSE Index & Insurance \\
\hline Monetary Policy & 99.96 & 0.01 & 0.03 \\
NSE Index & 7.03 & 92.65 & 0.32 \\
Insurance & 9.43 & 0.78 & 90.49 \\
Contribution Inc. own & 116.42 & 93.44 & 90.84 \\
Net Volatility & 16.42 & -6.56 & -9.16 \\
\hline
\end{tabular}

Source: Authors Calculations

\subsection{Impulse Responses Shocks to Financial Inclusion}

Figure 4 shows impulse responses to and from household credit. The results show that, while there is no impact of shocks from Loan uptake and stock market development there is a positive movement of shock transmission from stock market to household credit. This implies that a good stock market performance increases confidence in using and
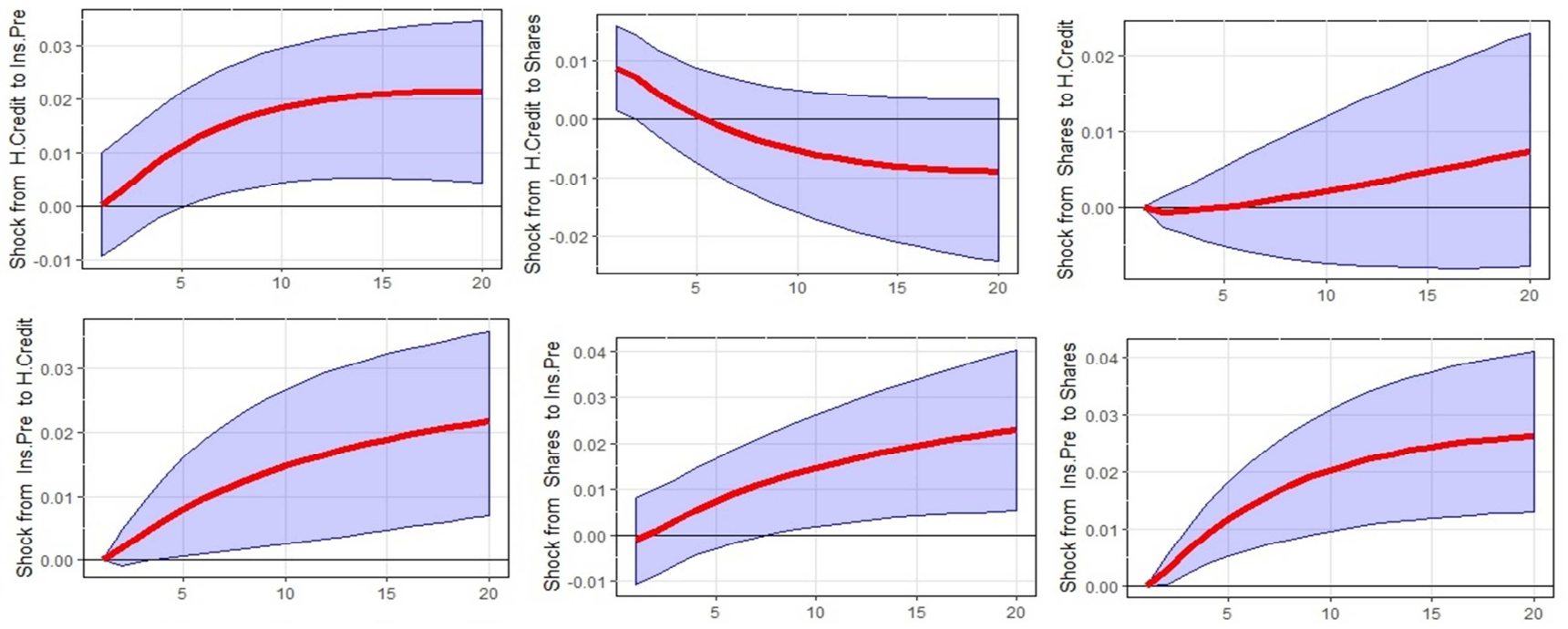

accessing bank services due to increased money supply and liquidity supply. This study contradicts the findings by Levine and Zervos [11] who found that stock market liquidity and banking development are both positively and robustly correlated. This study only finds the correlation one way from stock markets to the banking sector.

Figure 4. Response Impulses for Household Credit and Other Markets.

The most interesting result is that, as household credit which is a measure of financial inclusion increases, lending rates decreases as in the short run but bounces back to normal between 6-12 months.

Similarly, a reduction in household credit uptake leads to negative impact in the capital markets. Similarly, the author found that the impact of changes in net premiums does not affect Lending rates and foreign exchange rates, but it does affect credit uptake and stock performance on the Nairobi Securities Exchange. Particularly, one standard deviation shock positive shock in net premiums impacts significantly on credit uptake and performance of stock markets. This 
uptake leads to improved, performance of other markets. This is confirmed by the fact that one standard deviation positive shock in loan uptake leads to significant influence in performance of Insurance premiums and even foreign exchange rates. It is evident from the analysis that one standard deviation negative shock in credit uptake leads to significant negative performance of Nairobi securities exchange. This demonstrates the influence of banks on stock markets and other markets. Interestingly, one standard deviation positive shock in credit uptake tends to influence positive shocks in lending rates. This further confirms that loan uptake is not influenced by interest rates but on the contrary, if more customers can access credit, then increased credit in the market will lead to improved lending rates as banks gear towards rewarding their customers due to the verge of increased competition.

The Most important finding which supports the common theory and understanding was that lending rates shocks affected all market segments albeit in the short run just as expected. This signals that not only does the monetary policy transmission affect the banking sector but also indicates the transmission of commercial banks shocks to other financial markets. Specifically a negative shock in lending rates reduced the loan uptake, Capital market performance and even reduced the net premiums in the insurance sector.

Lending rates also greatly influenced the foreign exchange rate fluctuation in terms of currency depreciation. This indicates influence of monetary policy and banking dominance over other markets. Generally, and just like expected, there is a strong transmission of monetary policy to the entire financial sector affecting mostly the banking sector in the short run and other financial segments shortly afterwards. The channel of transmission of shocks generally moves from commercial banks to other markets but there is insignificant movement of shock transmission from other markets to banking segment, this potentially confirms the dominance of banking sector in Kenya over other markets.

Using a 10-step ahead forecasts variance decomposition (Table 4), results agree with the impulse response functions in the sense that monetary policy (banking interest rates) is the sole contributor of volatility to other markets (Stock market and Insurance) and to financial inclusion as well.

Table 4. Decomposition of Forecast Errors for a Market interactions (Forex).

\begin{tabular}{llllll}
\hline & Credit & Monetary Policy & NSE Index & Insurance & Forex \\
\hline Credit & 95.47 & 2.08 & 1.08 & 1.35 & 0.02 \\
Monetary Policy & 0.05 & 99.94 & 0 & 0 & 0.01 \\
NSE Index & 0.02 & 1.61 & 97.92 & 0.22 & 0.23 \\
Insurance & 0.69 & 7.77 & 0.76 & 90.74 & 0.04 \\
Forex & 0.28 & 31.19 & 0.05 & 1.87 & 66.61 \\
Contribution Inc. own & 96.51 & 142.59 & 99.81 & 94.18 & 66.91 \\
Net Volatility & -3.49 & 42.59 & -0.19 & -5.82 & -33.09 \\
\hline
\end{tabular}

Source: Authors Calculations

Monetary policy contributes about $42.59 \%$ to other markets with foreign exchange markets being the largest recipient at $33 \%$ followed by insurance sector at about $6 \%$. Financial inclusion absorbs about $3.5 \%$ of market volatility from the banking sector. Interestingly, the stock market is the least recipient of banking sector shocks at only $0.2 \%$. This result confirms the commanding influence of the banking sector on other markets through the monetary policy. The least effect of markets shocks on stock implies that stock markets could be influenced by other factors other than banking sector shocks. These factors could include foreign exchange, economic growth, performance of specific company returns and the investor behavior and influence. With the stock market being the least recipient at only $0.2 \%$ and the Foreign exchange market being the biggest recipient at $33.1 \%$ confirms the conventional belief is that strong equity markets are accompanied by currency appreciation.

Equally, the same conventional knowledge implies that, when share prices rise, investors gain confidence in the country economic and investment growth or recovery in situation where it had flopped. This in turn could foster foreign investors to trickle in and hence bring more inflow of foreign funds. These foreign funds would lead to a higher demand for local currency to enable transactions take place for local investment in the capital markets. Therefore, this means that the stock market can steer itself to equilibrium incases of negative shocks from the monetary policy even though the monetary policy contributes very little to the markets. Finally, the results indicate that credit uptake contributes to the lending rates by about $0.05 \%$. This also confirms the results from the impulse response function on credit and lending rates relationship. This is a clear indication that increase in the uptake of credit could lead to favorable lending rates by about $0.05 \%$.

\section{Conclusion and Policy Recommendations}

\subsection{Conclusion}

The main objective of this research study was to investigate the intra-market linkages within the financial sector (Banking, Insurance and the Capital Markets). The second, objective was to measure the effect of this market interactions on financial inclusion. This research employed the use of impulse response functions of a structural VAR model under Cholesky decomposition of the forecast error 
variance decomposition. The results indicate that there is significant market interactions and interlinkages with significant shocks transmission moving from banks to other markets. Equally these market interactions enhance financial inclusion and financial intermediation through financial spillovers and increased loan uptakes regardless of lending rates. These two findings provide the feedback to the researcher's two main objectives. Interest rates shocks used as both a measure of monetary policy and commercial banks shocks transmission affected all markets. This means that monetary policy transmission as expected trickles down to the entire financial sector. This finding also means that Commercial banks still commands the financial market as a dominant player. Interestingly, positive shocks from credit impacts positively on lending rate and the capital markets performance implying banking mechanism to reward increased loan uptake at cheaper prices and hence creating cash flow that spills over to more investment on the securities exchange. Even though foreign exchange did not have a significant effect on lending rates and the household credit, it generally had a significant effect on the stock market implying that investment of the stick market is not only domestic but also affected by foreign investment through remittances in foreign currency. However, lending rates and household credit had a significant effect on the fluctuation and general currency depreciation. Future studies may further explore the same idea employing different dimensions like the Markov Regime Switching Model.

\subsection{Policy Implications}

From the results, this study finds that Banking sector is still dominant and significant transmission of shocks is dominantly one way from banks to other markets. As such Monetary policy, which largely is meant to control the flow and supply of money in the market not only affects banks but spills over to other markets. Therefore, any adverse effects of Monetary Policy on Finance (savings and credit) volatilities can affect financial inclusion in the long run. The author therefore recommends policy makers to design policies that help minimize the adverse impact of volatility/shocks but create opportunities for growth on each market to foster price stability and enhance economic growth through financial inclusion.

\section{Acknowledgements}

I thank Kenya Bankers Association (KBA) for accepting this paper to be presented to the 6th Kenya Bankers Association (KBA) Conference in September 2017.

\section{Appendix}
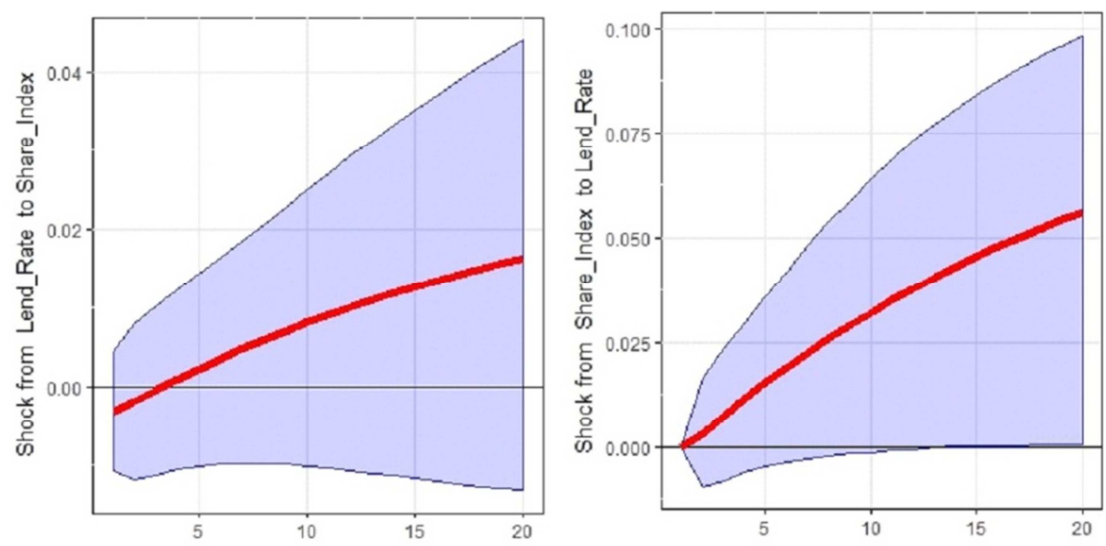

Figure 5. Response Impulses for Lending rates and Share Index.
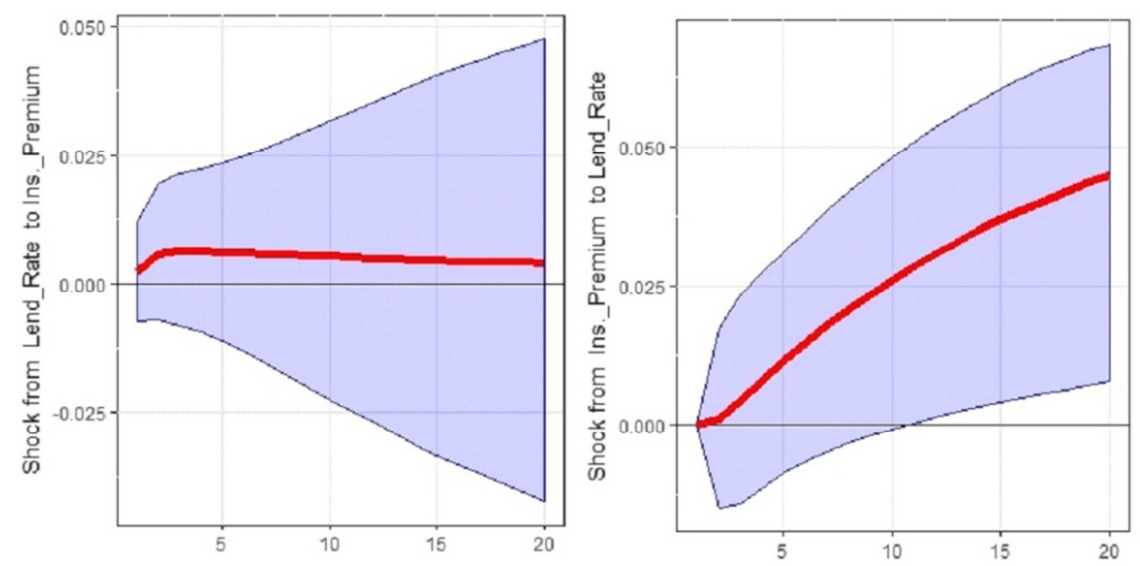

Figure 6. Response Impulses for Lending rates and Insurance Premium. 

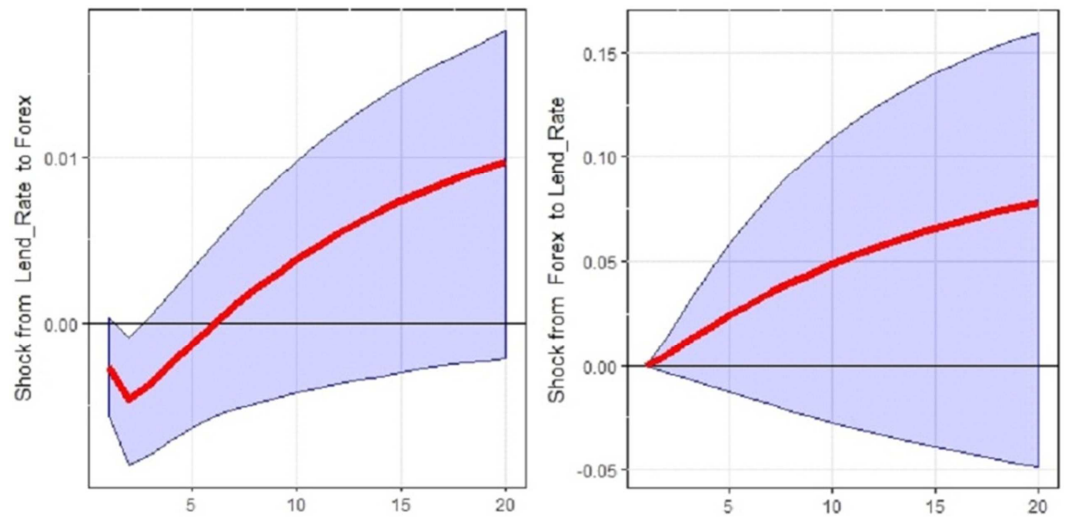

Figure 7. Response Impulses for Lending rates and Foreign Exchange rates.
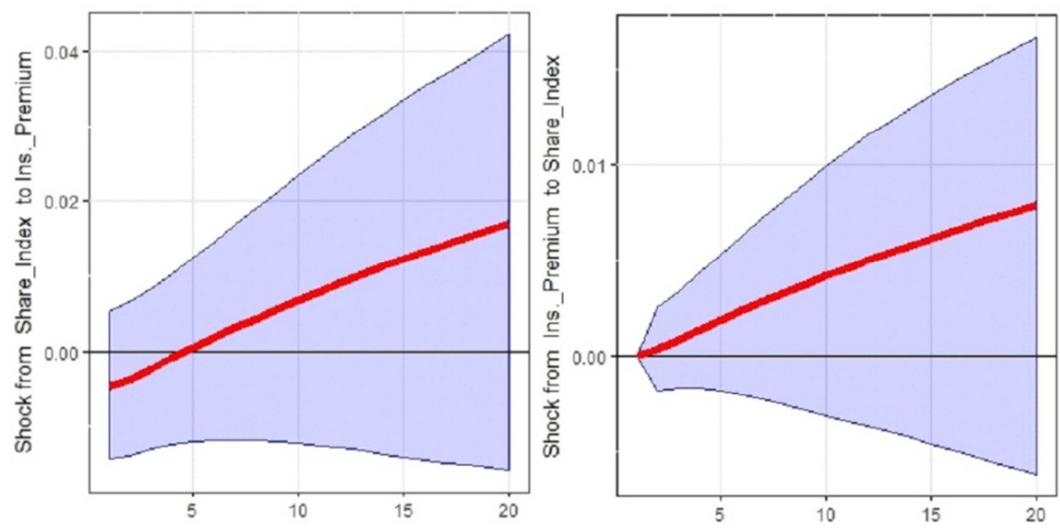

Figure 8. Response Impulses for Share Index and Insurance premium.
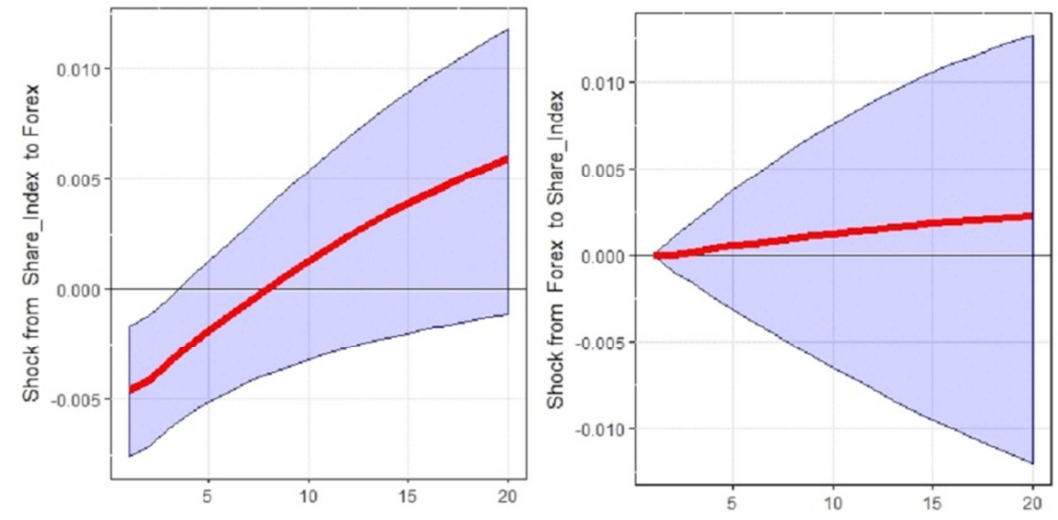

Figure 9. Response Impulses for Share index and Foreign exchange.
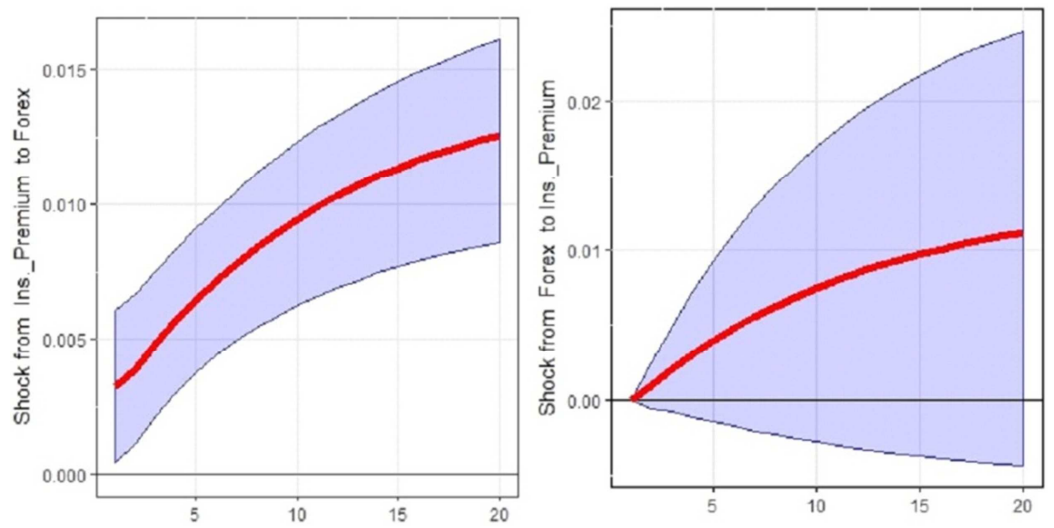

Figure 10. Response Impulses for Insurance Premium and Foreign exchange. 


\section{References}

[1] Sahay, R., Cihak, M., N'Diaye, P., \& Barajas, A. (2015). Rethinking financial deepening: Stability and growth in emerging markets. Revista de Economía Institucional, 17(33), 73-107.

[2] Chakrabarty, K. C (2011, September). Financial Inclusion (Keynote Address), Mumbai.

[3] Cheng, X., \& Degryse, H. (2010). The impact of bank and nonbank financial institutions on local economic growth in China. Journal of Financial Services Research, 37(2-3), 179199.

[4] Cevik, S., \& Teksoz, K. (2013). Lost in Transmission? The Effectiveness of Monetary Policy Transmission Channels in the GCC Countries. Middle East Development Journal, 5(3), 1350018-1.

[5] Gali, J., \& Gambetti, L. (2015). The effects of monetary policy on stock market bubbles: Some evidence. American Economic Journal: Macroeconomics, 7(1), 233-257.

[6] Cummins, J. D., Lewis, C. M., \& Wei, R. (2006). The market value impact of operational loss events for US banks and insurers. Journal of Banking \& Finance, 30(10), 2605-2634.

[7] Kim, H. S. (2008). Spillover Effects of Pension Funds on Capital Markets: The Mechanism and Preconditions. http://ssrn. com/abstract $=2805804\}$.

[8] Chodorow-Reich, G. (2014). Effects of unconventional monetary policy on financial institutions (No. w20230). National Bureau of Economic Research.

[9] King, R. G., \& Levine, R. (1993). Finance, entrepreneurship and growth. Journal of Monetary economics, 32(3), 513-542.

[10] King, R. G., \& Levine, R. (1993). Finance and growth: Schumpeter might be right. The quarterly journal of economics, 108(3), 717-737.

[11] Levine, R., \& Zervos, S. (1998). Stock markets, banks, and economic growth. American economic review, 537-558.

[12] Wei, C. C. (2008). The analysis of interest rate mean and volatility spillover to the industrial production index and stock markets: The case of China. Economics Bulletin, 3(65), 1-14.

[13] Serwa, D., \& Wdowinski, P. (2016). Macro-financial linkages in the Polish economy: combined impulse-response functions in SVAR models.

[14] Sims, C. A. (1980). Macroeconomics and reality. Econometrica: Journal of the Econometric Society, 1-48.

[15] Chen, F. Y., \& Liao, S. L. (2009). Modelling VaR for foreignasset portfolios in continuous time. Economic Modelling, 26(1), 234-240

[16] De Medeiros, O. R., Van Doornik, B. F. N., \& de Oliveira, G. R. (2011). Modeling and forecasting a firm's financial statements with a VAR-VECM model. CEP, 70843, 030.

[17] Pecican, E. S. (2010). Forecasting based on open VAR model. Romanian Journal of Economic Forecasting, 13(1), 59-69.

[18] Sims (2007) Bayesian Methods in Applied Econometrics, or, Why Econometrics Should Always and Everywhere Be Bayesian. Technical Report, Princeton University Villani.

[19] Villani, M. (2009). Steady-state priors for vector autoregressions. Journal of Applied Econometrics, 24(4), 630650 .

[20] Tsay, R. S. (2005). Analysis of financial time series (Vol. 543). John Wiley \& Sons.

[21] Sims, Christopher A. and Tao A. Zha. 1998. "Bayesian Methods for Dynamic Multivariate Models." International Economic Review 39(4): 949-968.

[22] Adenomon, M. O., Michael, V. A., \& Evans, O. P. (2016). On the Performances of Classical VAR and Sims-Zha Bayesian VAR Models in the Presence of Collinearity and Autocorrelated Error Terms. Open Journal of Statistics, 6(01), 96-132. 